\title{
Flest spermiemutasjoner hos eldre fedre
}

\section{Sekvensering av genomet hos \\ 78 islandske far-mor-barn-grup- \\ per viste at antall mutasjoner \\ i det befruktede egget økte med \\ fars alder, men ikke med mors.}

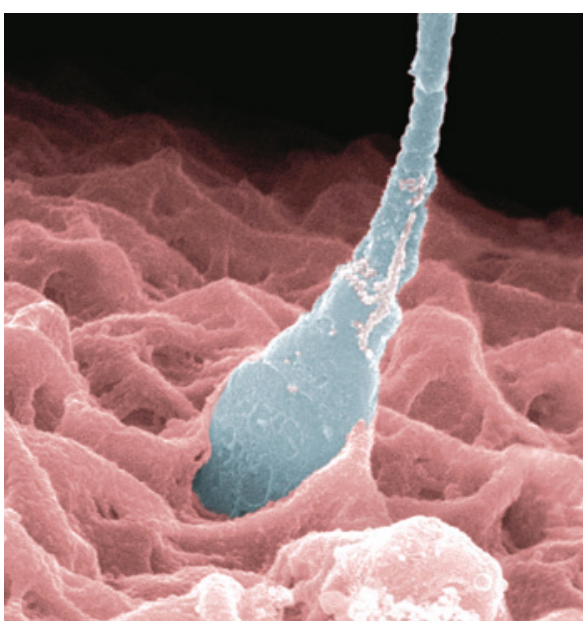

Illustrasjonsfoto Science Photo Library/NTB Scanpix
Ved å sammenlikne genotypen til far, mor og avkom i det store islandske DNA-sekvenseringsprosjektet fant man at et nyfødt barns genom gjennomsnittlig inneholdt 60 nye mutasjoner (1). Antallet var avhengig av fars alder på konsepsjonstidspunktet. Mens en 20-årig far gjennomsnittlig overførte $25 \mathrm{mu}-$ tasjoner til barnet, overførte en 40-åring 65. Mor bidro med omtrent 15 nye mutasjoner uavhengig av alder. I motsetning til spermieforløperne deler ikke eggene seg fra mor ble født til egget er befruktet. Siden omtrent 10\% av punktmutasjoner anses som skadelige, kan dette samlet sett tenkes å ha betydelige helseeffekter. Det er ikke urimelig å sette økt prevalens av bl.a. autisme i forbindelse med økt høyere alder hos far. Burde menn i ungdommen få fryst ned og lagret sine spermier til senere fertilisering?

- Jeg tror det er for tidlig å trekke denne typen slutninger, sier professor Dag E. Undlien ved Avdeling for medisinsk genetikk, Oslo universitetssykehus. - Det er imidlertid veldig interessant at mutasjonshyppigheten ser ut til å være forskjellig hos mor og far, og at hyppigheten øker med fars alder. For kromsomavvik som trisomi 21 er det jo motsatt, der øker risikoen med økende alder hos mor, sier han.

- Det er i seg selv interessant å få et tall på mutasjonshyppigheten $\mathrm{i}$ en generasjon. Sammenhengen mellom mutasjonshyppighet og alder kan muligens forklare noen epidemiologiske observasjoner om sammenheng mellom fars alder ved konsepsjonstidspunktet og sykdom hos avkommet. Det er i løpet av de siste årene kommet studier, for eksempel av barn med mental retardasjon, som viser at nyoppståtte mutasjoner kan forklare flere sykdomstilfeller enn vi tidligere har trodd, sier Undlien.

\section{Haakon B. Benestad}

h.b.benestad@medisin.uio.no

Universitetet i Oslo

\section{Litteratur}

1. Kong A, Frigge ML, Masson $G$ et al. Rate of de novo mutations and the importance of father's age to disease risk. Nature 2012; 488: 471-5.

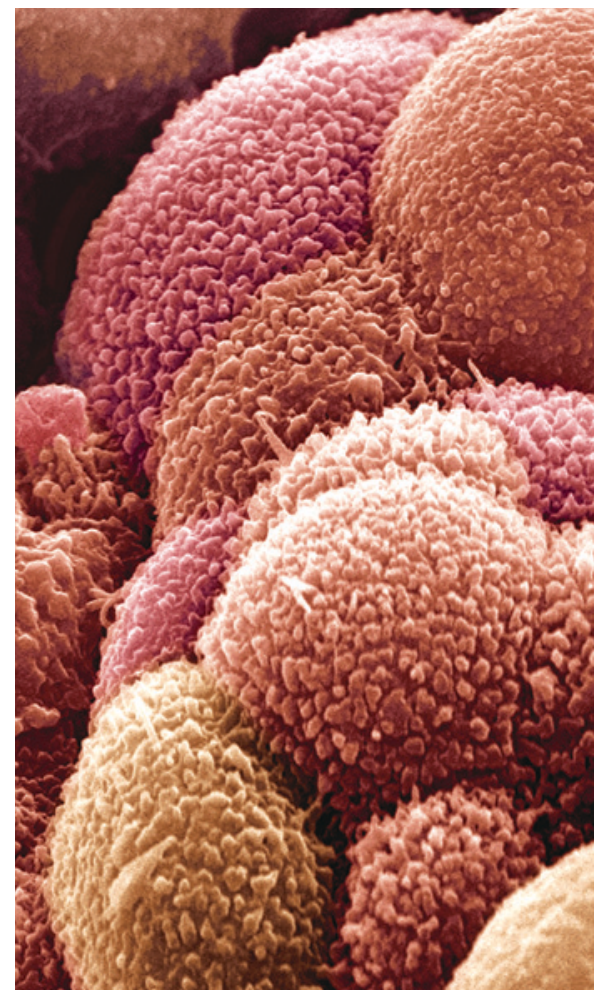

Illustrasjonsfoto Science Photo Library/NTB scanpix

\section{Gynekologer misoppfatter risikoen for eggstokkreft og praktiserer \\ ikke screening i tråd med anbefalingene, ifølge en amerikansk studie.}

To av tre tilfeller av eggstokkreft blir diagnostisert sent i forløpet - med utbredt spredning. Derfor har man hatt forhåpninger til screeningstrategier basert på vaginal ultralydundersøkelse og/eller Ca125, en svulstmarkør. Studier har imidlertid vist at disse strategiene ikke virker - mortaliteten blir ikke redusert. Samtidig har strategien vist seg å være skadelig pga. kirurgiske komplikasjoner hos kvinner med falskt positivt screeningresultat. Det er derfor bred enighet om å fraråde denne formen for screening.

I en spørreundersøkelse blant amerikanske leger var $28 \%$ positive til screening av kvinner $\mathrm{i}$ en generell lavrisikopopulasjon (1), mens hele $65 \%$ var positive til screening av dem med antatt moderat økt risiko, bl.a. på bakgrunn av en positiv slektsanamnese. Rutinemessig årlig screening av lavrisikokvinner ble rapportert av $6 \%$ av legene, av kvinner med antatt økt sykdomsrisiko av $24 \%$.

- Denne studien dokumenterer at risikoen for eggstokkreft ofte overestimeres. Det er en viktig bakgrunnsfaktor for feilaktig vur- dering og praktisering av screening, sier overlege Bjørn Hagen ved Kvinneklinikken, St. Olavs hospital.

Andre viktige faktorer for brudd med faglig konsensus var pasienters ønsker, om legen arbeider $\mathrm{i}$ solopraksis og om legen hadde praktisert i mer enn ti år.

- Studien viste at andelen amerikanske leger med feil kunnskap og feil praksis ved screening for eggstokkreft var høy. I tillegg til faglig svikt kan også økonomiske hensyn ha spilt inn. Relevansen til norske forhold er vanskelig å vurdere, sier Hagen.

\section{Geir W. Jacobsen}

geir.jacobsen@ntnu.no

Tidsskriftet

\section{Litteratur}

. Baldwin L-M, Trivers KF, Matthews B et al. Vignette-based study of ovarian cancer screening do U.S. physicians report adhering to evidencebased recommendations? Ann Intern Med 2012 156: 182-94. 